\title{
Seismic strain and seismogenic stress regimes in the crust of the southern Tyrrhenian region
}

\author{
G. Neri ${ }^{a, *}$, G. Barberi ${ }^{b}$, B. Orecchio ${ }^{a}$, A. Mostaccio ${ }^{b}$ \\ a Dipartimento di Scienze della Terra, Università di Messina, Salita Sperone 31, 98166 Messina, Italy \\ b Istituto Nazionale di Geofisica e Vulcanologia, Sezione di Catania, Catania, Italy
}

Received 7 January 2003; received in revised form 12 March 2003; accepted 19 May 2003

\begin{abstract}
An investigation has been performed to identify and characterize the seismic deformation zones active over the last decades in the region of Italy that has experienced the strongest seismicity during the last centuries. The study is based on the estimate of hypocenter locations, fault plane solutions, seismogenic stress and seismic strain tensor orientations carried out using the entire dataset of the national and local seismic networks, and the recently improved threedimensional (3D) crustal velocity model of the study area. A series of simulation tests have been performed to evaluate the significance of the earthquake space distribution obtained and whether it was influenced by network geometry problems related to the sea and the lack of ocean bottom seismometers. In the sectors where hypocentral location was synthetically proved to be reliable, space distributions of earthquakes located with epicenter and focal depth errors less than 3 and $4 \mathrm{~km}$, respectively, have been compared with local geology in order to identify seismogenic faults. The dataset of 32 fault plane solutions estimated with fault parameter errors less than $20^{\circ}$ has been used to investigate space variations of seismogenic stress and seismic strain orientations over the study area. Stress was found to be uniform in the Messina Strait and southern Calabria where inversion of the available set of 11 fault plane solutions showed clear evidence of an extensional regime. The different orientations of the minimum compressive stress and strain found in this sector, together with the information available on local geology and tectonics, lead us to propose that the seismicity occurring over the last decades in the Messina Strait and southern Calabria was not in general produced at the main faults, but at minor faults activated by the main tectonic stress field acting in the area. To the west, in the sector including western Etna, the Nebrodi chain and the western Aeolian Islands, analysis of the available set of 16 fault plane solutions revealed a certain degree of stress heterogeneity with an apparent prevalence of north-south compression. This east to west change of stress-strain regimes is evaluated in the light of current hypotheses regarding the geodynamics of the study region.
\end{abstract}

(C) 2003 Elsevier Science B.V. All rights reserved.

Keywords: crustal seismicity; seismic strain; seismogenic stress; Tyrrhenian sea; Italy

\footnotetext{
* Corresponding author. Tel. +39-90-6765102; Fax: +39-90-392333.

E-mail address: geoforum@unime.it (G. Neri).
}

\section{Introduction}

We investigate the crustal seismicity that occurred between January 1978 and March 2001 in the area indicated by a rectangle in Fig. 1a, 
e.g. the one which has experienced the strongest earthquakes affecting the Italian region over the last 3 centuries: these were the magnitude 7-7.5 earthquakes of (i) February 5, 1783 in southern Calabria, (ii) September 8, 1905 in the S. Eufemia Gulf, and (iii) December 28, 1908 in the Messina Strait (Fig. 2; [2]). Seismic strain release in this area is one of the most evident effects of the dynamics of the Ionian, southern Tyrrhenian and Sicilian tectonic units, these being some of the lithospheric blocks and microplates identified in the highly fragmented Italian portion of the Africa-Eurasia contact belt [3-6].

The present study mainly focuses on earthquake hypocenter locations and fault plane solutions, with the main goal of identifying the most active zones and their strain styles during the period of investigation. We enlarged the seismic dataset used in the last investigations performed in the same area [7-10] by including, in particular, the data of the earthquakes that occurred after 1995. The enlarged dataset and the use of Neri et al.'s local velocity model [11] that is more accurate than those available for the past investigations, allow us to upgrade the knowledge of the seismicity of the study area. The information coming from the present study will add to the notable amount of data published in the last years for this region concerning the structure of the crust $[3,5,11]$ and upper mantle [12-15], the structural geology and tectonic processes [16-19].

\section{Geodynamic features of the study area}

Many investigators ([5,20-26] among others) suggested that geological and geophysical evidences in the southern Tyrrhenian region can be interpreted in the framework of a geodynamic model assuming gravity-induced southeastward rollback of a Ionian lithosphere slab subducting beneath the Tyrrhenian lithosphere (Fig. 1a,b). Rollback is widely believed to have been the primary tectonic source for (1) the southeastward kinematics of the southern Tyrrhenian lithosphere, (2) its thinning and overthrusting onto the Ionian lithosphere, and (3) the Tyrrhenian basin opening. Starting from geologic informa- tion, upper mantle seismic tomography and results from laboratory experiments, Faccenna et al. $[23,24]$ proposed that the slab actively subducted until beneath Provence before the Oligocene, while trench retreat in the last $30 \mathrm{Myr}$ led to the formation of the Liguro-Provencal and Tyrrhenian small ocean basins in a chronological order (the last phase of this process is schematically represented in Fig. 1b). Slab detachment beneath the Calabrian Arc in recent times has been suggested by several investigators ([18]; among others) to explain the uplift of the arc in the last 1-0.7 Myr. Negredo et al. [27] used neotectonic and GPS data of the Italian region as reference data to elaborate a three-dimensional (3D) finite element modelling of the regional geodynamics: in this model the slab is not detached yet and the recent uplift of the Apenninic chain is interpreted as a result of the joint action of southeastward rollback of the Ionian slab and north-south Africa-Europe convergence. The continuity of the subducting slab also seems supported by the distribution of the deep earthquakes [28], the upper mantle seismic tomography $[12,13,29]$ and the high-frequency seismic wave propagation [30]. Alternative modelling of the regional geodynamics was proposed by Mantovani et al. [31-33] who explained the strain pattern in the Mediterranean area by adopting the convergence of the African, Arabian and Eurasian blocks as the only driving mechanism of tectonic activity in the region. Debate on the most appropriate model is still open, basic constraints are in particular expected from current developments of geodetic monitoring [34].

Using data from exploration geophysics and geology, Finetti and Del Ben [35] concluded that ca. NW-SE faults accomodated the southeastward migration of the southern Tyrrhenian lithosphere (Fig. 1a and c). They also suggested that migration gradually decreased in intensity since the Upper Pliocene. The Taormina, Sisifo and Vulcano fault systems in the southernmost Tyrrhenian area and northeastern Sicily (Fig. 1c) were proposed by the same authors as major dislocation zones accomodating the migration process. This confirmed the main role that had been previously assigned to the Taormina and Vulcano lines on the grounds of the surface geology data 
a)

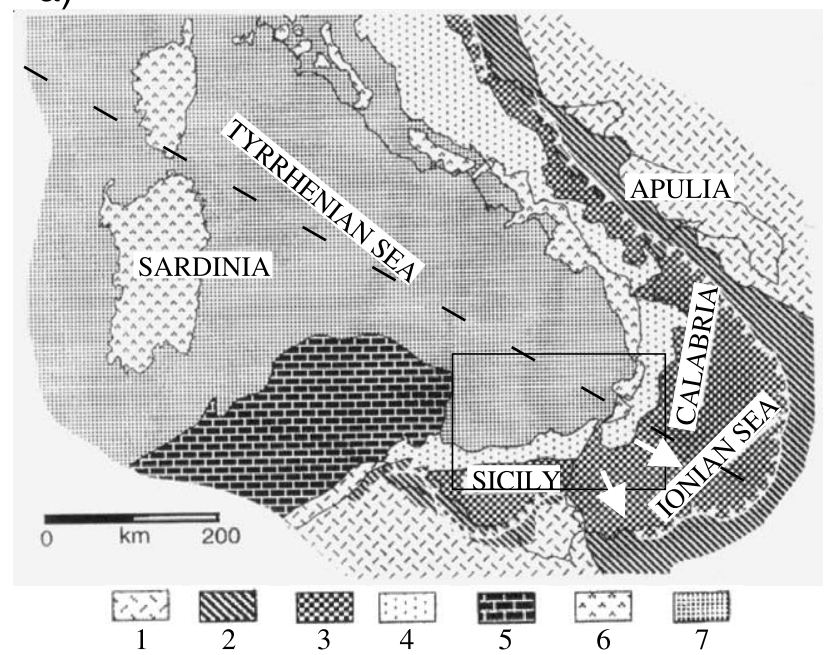

b)

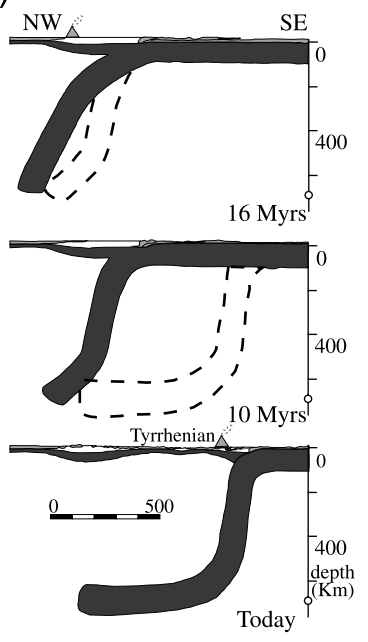

c)

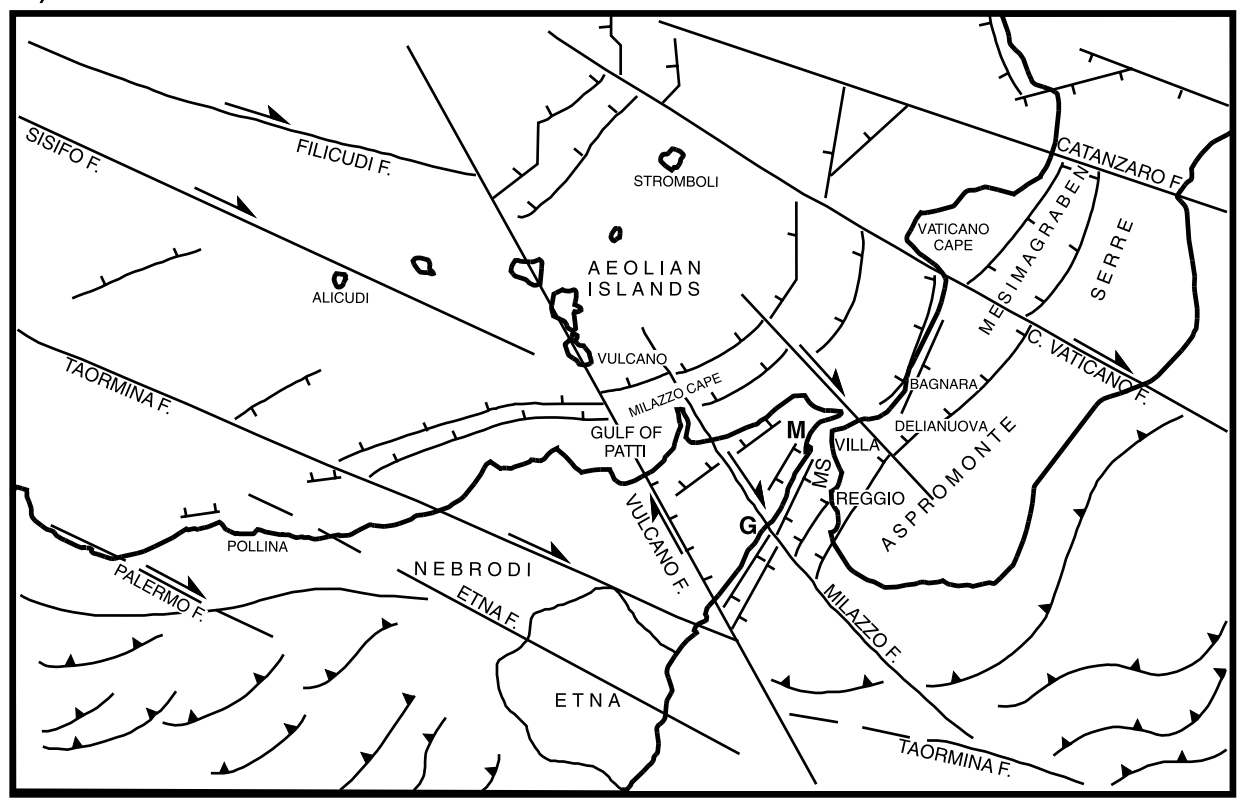

Fig. 1. Main tectonic and structural features of the study area. (a) Neotectonic map of Italy modified from [1]. The line of white triangles represents the outermost belt of the Pliocene-Pleistocene thrusts. 1: Pliocene foreland and Pliocene-Quaternary foreland (uplift); 2: Pliocene-Quaternary foredeep (subsidence); 3: Pliocene foredeep (subsidence); 4: Apenninic-Maghrebian chain (uplift); 5: Apenninic-Maghrebian chain (subsidence); 6: pre-Pliocene chains (uplift); 7: pre-Pliocene chains (subsidence). The Ionian lithosphere is subducting northwestward beneath the Tyrrhenian area. The white arrows mark the sense of subduction trench retreat. The NW-SE dashed line indicates the profile of the vertical section of $b$. The rectangle shows the area investigated in the present study, the structural map of which is given in c. (b) Evolution of subduction in the central Mediterranean during the last $16 \mathrm{Myr}$ according to Faccenna et al. [24]. The profile of this vertical section is shown in a. (c) Main fault systems in the study area. Data for the subaerial areas are from [16-19,36,39,40], data for the submarine areas are from [35,58]. In agreement with standard symbology, barbs indicate the downthrown blocks in normal faults, arrows show the strike-slip component of the fault mechanism, black triangles indicate the sense of dipping of thrust structures. MS, M and G stand for Messina Strait, Messina and Giardini, respectively. Discrepancies in the fault data reported by different authors (see e.g. [16,36] for northeastern Sicily; and $[18,39]$ for southern Calabria) do not influence the conclusions of the present study. 
of northeastern Sicily [36]. More recent geologic data collected in northeastern Sicily [16] further supported Finetti and Del Ben's kinematic scheme which, however, is widely shared in the literature ([37,38]; among others). Tensional mechanisms are dominant along the Ionian coast of Sicily (Fig. 1c), in particular on the Messina-Giardini fault system $[3,5,18,19,39,40]$. To the northeast, a curved belt a few tens of $\mathrm{km}$ wide following the shape of the Calabrian Arc (Fig. 1a and c) includes strongly contrasting movements, e.g. uplift of the mountain chain on the eastern side of the belt and relative to chain subsidence in the major tectonic troughs on the western side $[18,19,39,40]$. It is held that these contrasting movements are due to complex dynamics associated with overthrusting of the Tyrrhenian crust onto the Ionian one (see e.g. [39]). The strongest earthquakes of the last 3 centuries in the study region (1783, 1905 and 1908; Fig. 2) occurred within the subsidence domain in the above-mentioned curved belt. On the grounds of geodetic and seismometric data, the 1908 event was interpreted in terms of activity of the Messina Strait

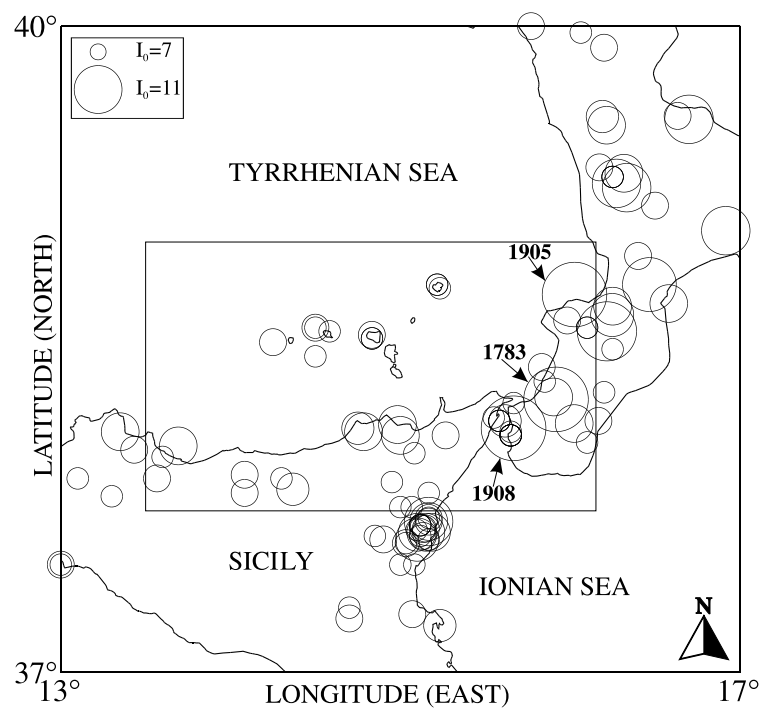

Fig. 2. Epicenter map of the earthquakes exceeding the damage threshold between 1700 and 1992 in the area $37-40^{\circ} \mathrm{N}$, $13-17^{\circ} \mathrm{E}$ (NT4.1 catalogue; [2]). The circle size is proportional to the epicentral intensity $I_{0}$. The rectangle shows the area investigated in the present study. graben ([41-43]; among others). Based on the analysis of geomorphological, structural and paleoseismological data, the 1783 earthquake was related to the Mesima basin dynamics [44-46].

\section{Data and methods}

$\mathrm{P}$ - and $\mathrm{S}$-wave arrival times, $\mathrm{P}$ onset polarities and duration magnitudes of the earthquakes shallower than $50 \mathrm{~km}$ occurring between January 1978 and March 2001 in the shadowed area of Fig. 3 were collected from the seismic networks of Istituto Nazionale di Geofisica e Vulcanologia and Cosenza, Messina and Catania universities. All the seismic stations operating in Sicily and Calabria during the investigation period furnished data for the present study, including the stations of the Istituto Internazionale di Vulcanologia $(C N R)$ and Sistema Poseidon (Dipartimento Nazionale di Protezione Civile), two research centers that recently became a part of the Istituto Nazionale di Geofisica e Vulcanologia. A map of the most used stations is shown in Fig. 3. The dataset was analyzed for hypocenter locations using Evans et al.'s location algorithm [47] and the 3D crustal velocity model proposed for the study area by Neri et al. [11]. Outwith this model's zone of reliability, i.e. where Michelini-McEvilly's Spread Function was found to be greater than 4.0 (Fig. 3 ; see [11] for details), the velocity values required for hypocentral locations were assumed on the grounds of the DSS information available in the literature. Figs. 4 and 5 show the earthquakes located with epicenter and focal depth errors less than 3.0 and $4.0 \mathrm{~km}$ respectively, standard deviation of the arrival time residuals less than $1.0 \mathrm{~s}$, and maximum azimuthal gap of the network around the epicenter less than $180^{\circ}$.

We performed the following synthetic test in order to establish in which part of the study area the network geometry may make hypocentral location uncertain. Theoretical arrival times at the stations indicated by full triangles in Fig. 3 were estimated in Neri et al.'s 3D model for a set of synthetic events located on the nodes of a grid covering the area of Fig. 4 with horizontal and vertical spacing of 2.5 and $5.0 \mathrm{~km}$, respectively. 


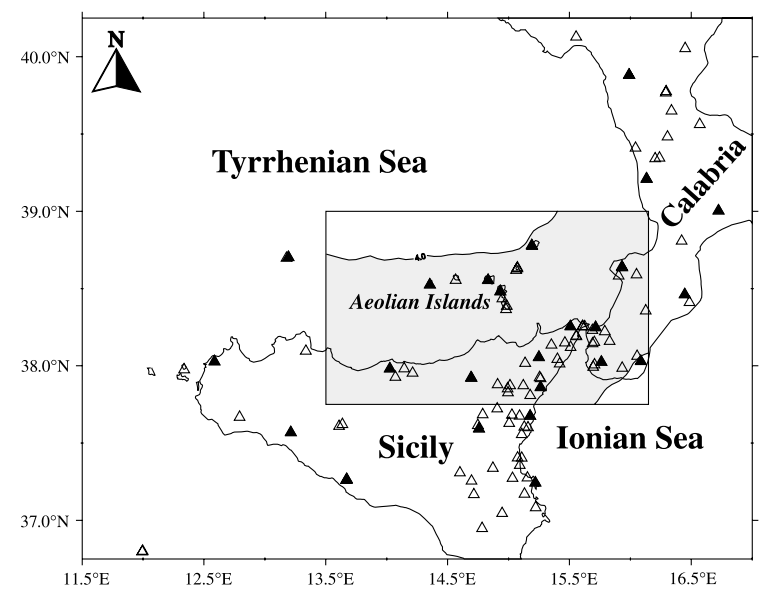

Fig. 3. The figure shows the map of the seismic stations most used in the present study (triangles), the area of our investigation (rectangle) and the reliability zone of the $3 \mathrm{D}$ velocity model used for hypocenter locations (this is indicated by darkening and corresponds to the area where Michelini and McEvilly's Spread Function was found to be less than 4.0 ; see [11] for details). Outside this reliability zone, the velocity values required for hypocentral location were assumed on the ground of the DSS information available in the literature. Full triangles indicate the stations used for the synthetic test performed to assess hypocentral location quality in the study area.

Station distribution was chosen as approximately representative of the network's low level of efficiency during our investigation of the real earthquakes. Synthetic arrival times of each event were inverted for hypocenter location using the same velocity model. Then, two parameters were estimated for each synthetic event (grid node), e.g. the epicentral distance $D$ and the focal depth difference $H$ between the original event (grid node) and the event after hypocentral location. Fig. 4a-f shows the space variation of the $D$ parameter at different depth levels $(5-30 \mathrm{~km}$, with $5 \mathrm{~km} \mathrm{step})$. Rather similar patterns (not reported for conciseness) were found for the $H$ parameter, even if the numerical values of $H$ resulted larger than the $D$ values by about $30 \%$. Based on these results we propose the real earthquake space distribution in the yellow zones of Fig. $4 \mathrm{a}-\mathrm{f}$ as reliable $(D<3.0$ $\mathrm{km})$, and the distributions in the orange (3.0 $\mathrm{km}<D<4.5 \mathrm{~km})$ and red $(D>4.5 \mathrm{~km})$ zones as doubtful. A significant number of real events in Fig. 4 may be lost in the orange and red zones because of the uncertain hypocentral location, and this may alter the earthquake spatial trends.

Hypocenter locations, 3D velocity structure and $\mathrm{P}$ onset polarity data were used to estimate the fault plane solutions of the earthquakes reported in Figs. 4 and 5 by the standard FPFIT algorithm [48]. The fault plane solutions estimated with an average error on fault parameters less than $20^{\circ}$ are reported in Fig. 6 and Table 1. These solutions were utilized to estimate the seismic strain tensor orientations in the study area (Fig. 7) using Wyss et al.'s algorithm [49] derived from Kostrov [50]. In this regard, earthquake magnitudes were converted into scalar moments by the relationship $\log M_{0}=1.5 M+16.27$ proposed for the Italian region by Kiratzi [51]. The use of other relationships like those proposed by Bakun [52] and $\mathrm{Zu}$ niga et al. [53] did not change significantly the results. Also, stress tensor inversion of earthquake fault plane solutions was performed by Gephart and Forsyth's method [54] for the same crustal volumes (earthquake subsets) analyzed for strain estimates. Finally, stress and strain directions were compared. They may be different because stress generally produces seismicity on pre-existing surfaces of weakness in the lithosphere (see e.g. [49]). The orientation of the weakness surfaces which were seismogenic under a given stress field during the study period controls the seismic strain orientation we find by Wyss et al.'s algorithm.

\section{Analysis of results}

Following the standard terminology, we can say that seismic activity was moderate in the study area during the period of investigation: maximum recorded magnitude was 5.7, and three events exceeded the magnitude threshold of 5.0. The locations of these events are indicated by full circles in Figs. 4 and 5: an event of magnitude 5.6 occurred in southern Calabria, e.g. in the area affected in the last centuries by earthquakes of magnitude 7-7.5, the other two events of magnitudes 5.5 and 5.7 were located to the west, in a sector where the historical earthquake catalogue [2] reports seismicity of maximum magnitude 

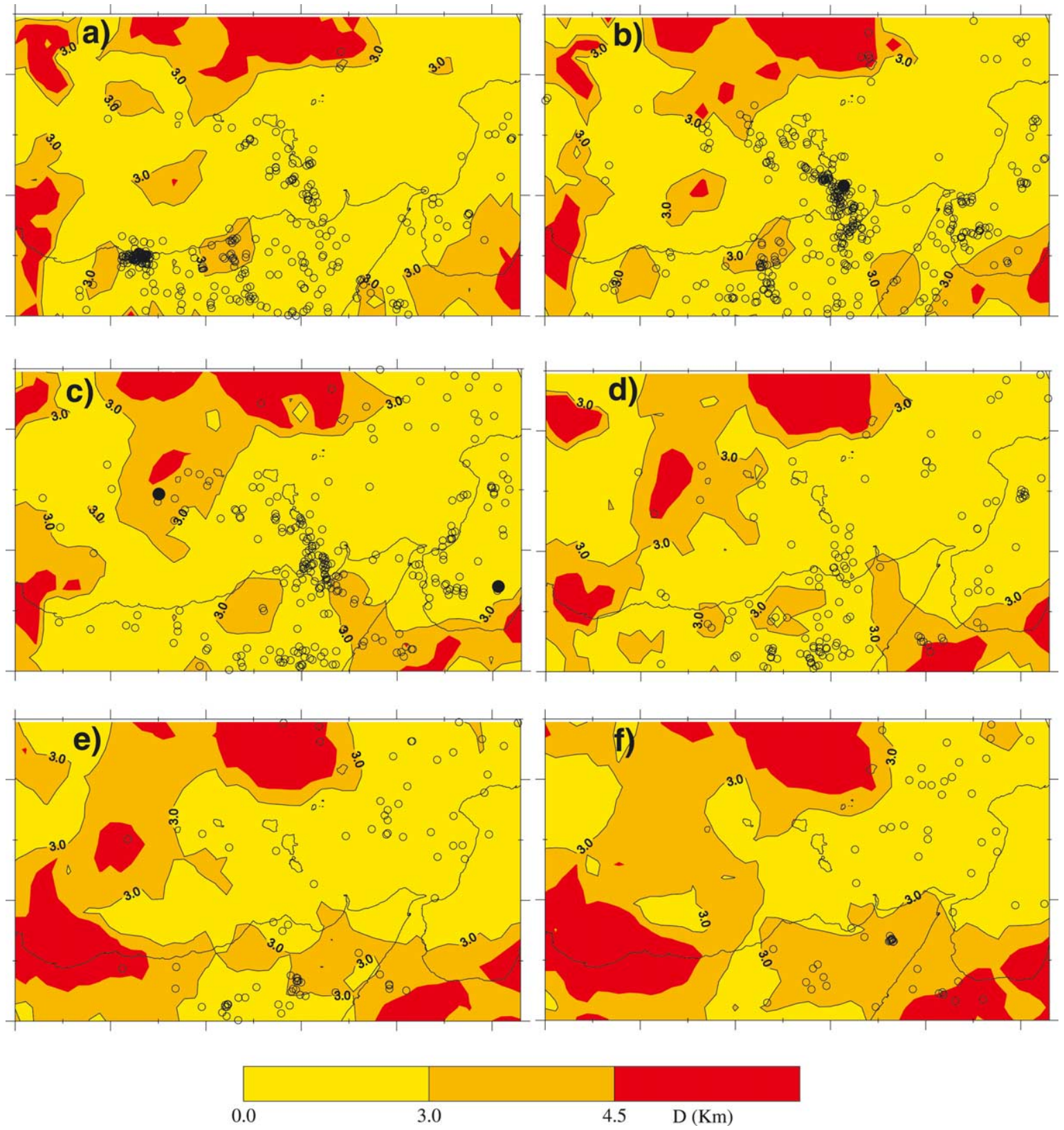

Fig. 4. Maps of the January 1978-March 2001 earthquakes located in the depth ranges 0-7.5 (a), 7.5-12.5 (b), $12.5-17.5$ (c), 17.5-22.5 (d), 22.5-27.5 (e) and 27.5-32.5 km (f), with ERH $<3 \mathrm{~km}$, ERZ $<4 \mathrm{~km}$, GAP $<180^{\circ}$ and RMS $<1.0$ s. The earthquakes of magnitude $\mathrm{M}>5.0$ are indicated by full circles. Colors show the values of the $D$ parameter estimated at depth levels 5 (a), 10 (b), 15 (c), 20 (d), 25 (e) and 30 (f) $\mathrm{km}$ in the synthetic test.

around 6 , therefore comparable with the strongest events recorded between 1978 and 2001.

Visual inspection of Fig. 4a-f leads us to identify some alignments of events suitable for com- parison with the fault traces reported in the geological maps. This analysis of earthquake spatial trends is performed in the yellow zones of Fig. $4 a-f$, e.g. in the zones where hypocentral location 
was proven to be of relatively good quality (Section 3). In some cases earthquake alignments are not very clear and this may be due to the low level of activity in the specific zone. These situations are presented with caution and need confirmation by future investigations with additional data. A clear NNW-SSE trend can be noted south of Vulcano island in Fig. 4a-d (depth range $0-22.5 \mathrm{~km}$ ). This trend corresponds to a segment of a welldocumented fault, named the Eolie-Tindari-Letoianni ([55]; among others) or the Vulcano fault [35]. The mechanism of this fault is a composition of normal faulting and dextral transcurrence $[39,55]$. The fault plane solutions obtained in the present study (Fig. 6) reveal normal faulting in the southern part of this seismic alignment (events 7, 14 and 29) and compressional mechanisms in the northern part (events 15 and 22). Fig. 4a-c (depth range $0-17.5 \mathrm{~km}$ ) indicate a northwestward prosecution of the trend, from the island of Vulcano to Alicudi approximately, with greater spreading of the events, however. The NW-SE seismic belt between the islands of Alicudi and Vulcano corresponds with the location of the Sisifo fault system (Fig. 1c), a structure where dextral strike-slip is considered to be dominant [35]. The fault plane solutions estimated in this area (nos. 1, 2 and 20 in Fig. 6) reveal normal faulting for the southernmost event and compressional mechanisms for the others.

Fig. 4a (depth range 0-7.5 km) shows an E-W earthquake trend along the Tyrrhenian coast of Sicily, near the western boundary of the study area. Most of the events of this group belong to the Pollina swarm that occurred in SpringSummer 1993 [56,57]. The main structural trends in this zone are oriented E-W and NW-SE (Fig. $1 c ;[35,36,58])$. The $\mathrm{E}-\mathrm{W}$ fault system is characterized by normal faulting. No fault plane solution of good quality was estimated in this zone in the present study. Vague information was reported by Azzara et al. [56] who generically spoke of a $\mathrm{N}$ to $\mathrm{NW}$ orientation of $\mathrm{P}$ axes for many events of the swarm. A less developed N-S earthquake trend can be observed in Fig. $4 a$ and $b$ (depth range $0-12.5 \mathrm{~km}$ ) about $30 \mathrm{~km}$ east of Pollina. The northern part of this trend lies outside the yellow zone. As observed for the Pollina zone, the main structural trends in this area are oriented E-W and NW-SE (Fig. 1c; [16,35,36]). However, minor faults trending between $\mathrm{N}-\mathrm{S}$ and NNW-SSE were locally mapped by Giunta and Nigro [59]. The two fault plane solutions estimated in this area (nos. 17 and 18 in Fig. 6) reveal normal faulting on planes oriented between $\mathrm{E}-\mathrm{W}$ and NW-SE, approximately. It is likely that most of the events in this zone occurred on a N-S minor fault, while the two events reported in Fig. 6 may have been produced by the activity of a main fault system.

The earthquakes located in the depth range 7.5-12.5 $\mathrm{km}$ beneath the southwestern edge of Calabria seem to define three consecutive segments in the plot of Fig. 4b, oriented ENEWSW (Bagnara-Villa), N-S (Villa-Reggio) and WSW-ENE (Reggio-Delianuova). With minor changes, this situation can be still noted in the depth range $12.5-17.5 \mathrm{~km}$ (Fig. 4c). The structural maps report normal faulting in the proximity of these earthquake trends: the faults are oriented ENE-WSW in the Bagnara-Villa area $[17,40]$, $\mathrm{N}-\mathrm{S}$ to the south of Villa [40] and SW-NE in the Reggio area [17,40]. Three fault plane solutions have been estimated in the area of the Reggio-Delianuova trend (nos. 4, 5 and 8 in Fig. 6) and one near Bagnara-Villa (no. 26): they do not depict a clear situation, even though the exten-

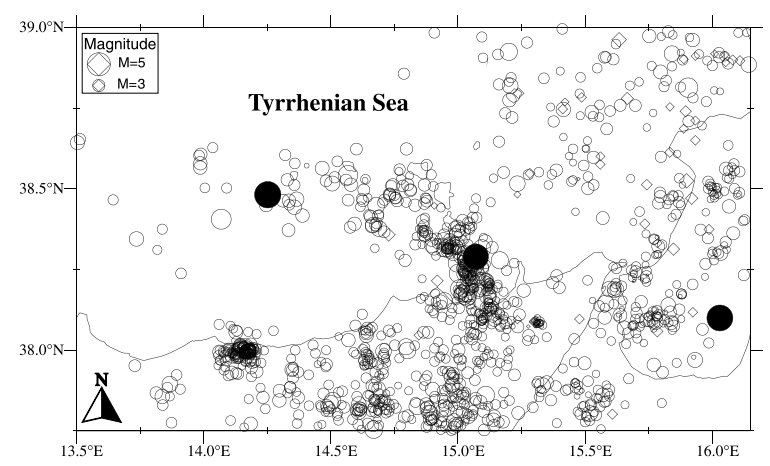

Fig. 5. Epicenter map of the events occurring between January 1978 and March 2001 at depth $<50 \mathrm{~km}$ in the study area, located with $\mathrm{ERH}<3 \mathrm{~km}, \mathrm{ERZ}<4 \mathrm{~km}, \mathrm{GAP}<180^{\circ}$ and RMS $<1.0 \mathrm{~s}$ using Evans et al.'s method [47] and Neri et al.'s 3D local velocity model [11]. Circles and rhombs indicate the events located in depth ranges $0-32.5 \mathrm{~km}$ and 32.5 $50 \mathrm{~km}$, respectively. Full circles indicate the events of magnitude over 5.0. 
sional nature of strain is evident for two of these earthquakes. Finally, we focus our attention on the other events located in Calabria and the Messina Strait. The layered representation in Fig. 4 does not show any evident trend in this regard, but the cumulative plot of seismicity in Fig. 5 seems to indicate a continuation of the ReggioDelianuova SW-NE trend northeast of Delianuova, roughly in correspondence with the eastern side of the Mesima graben [17,18,35,39,40]. Again, in Fig. 5 two small groups of events can be observed near Vaticano Cape, roughly in correspondence with the western side of the Mesima graben [35,39]. No fault plane solution is available in Fig. 6 for the Mesima graben zone and this lack of information, together with the modest level of activity, does not allow us to present a structural interpretation of the seismicity located in this zone. Fig. 5 also displays a SW-NE trend of events at the southern boundary of the Messina Strait but the significance of the finding is uncertain because this earthquake group is surrounded by areas where location quality is uncertain (see Fig. 4). The good-quality fault plane solutions in this sector (nos. 3, 10, 21, 24 and 25 in Fig. 6) show that normal faulting prevails. Two normal faulting solutions (event nos. 11 and 27) can also be seen in the area of the $M=5.6$ earthquake of March 1978.

Based on the space distribution of the earthquakes in Fig. 6 we can distinguish the following main groups of fault plane solutions:

1. 11 solutions in southern Calabria and the Messina Strait area (hereafter referred to as the CALMES group);

2. five solutions in the southeastern Tyrrhenian between Stromboli and Calabria (TYR);

3. eight solutions in the western Eolian Islands and Gulf of Patti area (WEOL);

4. six solutions in the Nebrodi chain area at the northern boundary of Mt. Etna volcano (NEB).

Two events in Fig. 6 do not belong to any of the groups listed above, i.e. the two westernmost events in the map that are both related to normal faulting. These events were previously discussed in this paper when analyzing the epicenter trend in the specific sector. Fig. $7 \mathrm{a}-\mathrm{f}$ show the orientations

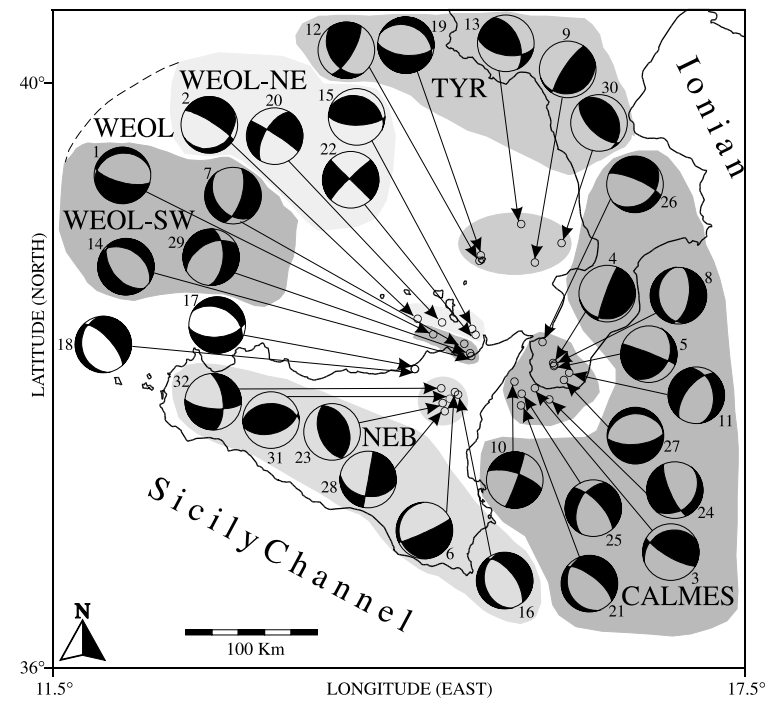

Fig. 6. Fault plane solutions (lower hemisphere projection) estimated in the present study with average error on fault parameters less than $20^{\circ}$ (focal parameter values are reported in Table 1). Different shades of gray indicate different groups of solutions (TYR, WEOL-NE, WEOL-SW, NEB, CALMES) defined on the basis of the space distribution of the events. WEOL includes the events of WEOL-NE and WEOL-SW.

of the principal strain axes $\left(\varepsilon_{1}=1, \varepsilon_{2}=2, \varepsilon_{3}=3\right)$ estimated for the earthquake groups listed above and for parts of them. The $95 \%$ confidence limits are shown for $\varepsilon_{1}$ and $\varepsilon_{3}$ orientations. Seismic strain orientations result poorly defined in the southeastern Tyrrhenian (TYR, Fig. 7a) and the Nebrodi area (NEB, Fig. 7e). On the contrary, the level of constraint of the solution is good or acceptable for the other groups of events (Fig. 7b-d and f). Strain style in the western Eolian Islands and Gulf of Patti area (WEOL) changes from southwest (extensional, Fig. 7d) to northeast (compressional, Fig. 7c), with the northeastern compressional regime dominating in an overall analysis of the WEOL zone (Fig. 7b) because of the larger magnitude values of the events. Extension is the primary factor in the generation of low-magnitude events (2.4-3.7) in southern Calabria and the Messina Strait area (CALMES, Fig. 7f). Fig. $7 \mathrm{~g}$ reports the strain orientations relative to the $M>5$ earthquakes occurring in March 1978 (southern Calabria), April 1978 (Gulf of Patti) and May 1980 (western Aeolian Islands). Fi- 
Table 1

Main parameters of the earthquakes reported in Fig. 6

\begin{tabular}{|c|c|c|c|c|c|c|c|c|c|c|c|c|c|c|c|c|c|c|}
\hline$N$ & Date & O.T. & $\begin{array}{l}\text { Lat } \\
\left({ }^{\circ} \mathrm{N}\right)\end{array}$ & $\begin{array}{l}\text { Long } \\
\left({ }^{\circ} \mathrm{E}\right)\end{array}$ & $\begin{array}{l}\text { Depth } \\
(\mathrm{km})\end{array}$ & Mag & GAP & RMS & $N_{\mathrm{P}}$ & $N_{\mathrm{S}}$ & Strike & Dip & Rake & $\begin{array}{l}\text { Er- } \\
\text { Str }\end{array}$ & $\begin{array}{l}\text { Er- } \\
\text { Dip }\end{array}$ & $\begin{array}{l}\text { Er- } \\
\text { Rake }\end{array}$ & $N_{\text {pol }}$ & Dis \\
\hline 1 & 880528 & $05: 57: 35.81$ & 38.282 & 14.798 & 19.24 & 3.1 & 89 & 0.38 & 15 & 4 & 105 & 70 & -80 & 3 & 8 & 10 & 12 & 1 \\
\hline 2 & 880530 & $10: 06: 36.81$ & 38.388 & 14.664 & 13.01 & 3.4 & 125 & 0.30 & 15 & 3 & 55 & 20 & -150 & 5 & 5 & 5 & 12 & 0 \\
\hline 3 & 880721 & $17: 18: 16.23$ & 37.914 & 15.679 & 30.98 & 2.7 & 146 & 0.22 & 16 & 7 & 120 & 75 & 110 & 10 & 8 & 15 & 10 & 1 \\
\hline 4 & 881107 & $14: 26: 54.45$ & 38.086 & 15.837 & 16.41 & 3.4 & 131 & 0.31 & 24 & 4 & 200 & 85 & 80 & 8 & 3 & 10 & 19 & 4 \\
\hline 5 & 881108 & $07: 02: 30.09$ & 38.066 & 15.844 & 15.69 & 2.4 & 148 & 0.39 & 14 & 6 & 30 & 30 & 10 & 5 & 3 & 5 & 10 & 1 \\
\hline 6 & 881211 & $23: 56: 32.83$ & 37.887 & 14.986 & 7.26 & 2.9 & 106 & 0.27 & 20 & 0 & 65 & 85 & -80 & 3 & 8 & 0 & 13 & 1 \\
\hline 7 & 900404 & $15: 03: 38.70$ & 38.217 & 15.067 & 10.40 & 2.6 & 77 & 0.42 & 18 & 8 & 35 & 65 & -60 & 5 & 5 & 20 & 12 & 2 \\
\hline 8 & 900915 & $03: 11: 01.35$ & 38.075 & 15.848 & 14.67 & 3.0 & 125 & 0.18 & 15 & 6 & 10 & 60 & -80 & 8 & 5 & 10 & 12 & 0 \\
\hline 9 & 910427 & $00: 57: 03.87$ & 38.772 & 15.679 & 34.41 & 3.1 & 119 & 0.36 & 19 & 0 & 75 & 15 & 130 & 3 & 5 & 5 & 12 & 0 \\
\hline 10 & 910907 & $05: 39: 19.20$ & 37.959 & 15.502 & 8.41 & 3.2 & 123 & 0.16 & 23 & 12 & 20 & 85 & -160 & 0 & 8 & 15 & 17 & 1 \\
\hline 11 & 910925 & $13: 21: 34.51$ & 38.019 & 15.976 & 7.91 & 3.3 & 172 & 0.29 & 17 & 6 & 350 & 40 & -130 & 8 & 5 & 5 & 11 & 0 \\
\hline 12 & 911003 & $02: 40: 28.59$ & 38.784 & 15.199 & 7.32 & 3.7 & 123 & 0.30 & 24 & 7 & 145 & 40 & 30 & 10 & 13 & 10 & 11 & 0 \\
\hline 13 & 930509 & $01: 28: 12.39$ & 39.035 & 15.560 & 15.00 & 3.7 & 129 & 0.71 & 15 & 2 & 100 & 55 & 50 & 5 & 5 & 10 & 15 & 2 \\
\hline 14 & 930824 & $01: 20: 50: 52$ & 38.133 & 15.128 & 14.07 & 3.0 & 71 & 0.25 & 27 & 13 & 140 & 50 & -80 & 0 & 0 & 15 & 11 & 1 \\
\hline 15 & 940703 & $07: 05: 06.73$ & 38.319 & 15.135 & 28.60 & 3.0 & 61 & 0.85 & 23 & 13 & 90 & 65 & 80 & 5 & 5 & 5 & 15 & 2 \\
\hline 16 & 940706 & $13: 29: 52.70$ & 37.870 & 15.014 & 6.21 & 3.1 & 92 & 0.36 & 25 & 6 & 165 & 30 & -70 & 10 & 10 & 5 & 18 & 1 \\
\hline 17 & 940808 & $17: 38: 30.76$ & 38.046 & 14.636 & 9.19 & 3.3 & 85 & 0.28 & 25 & 0 & 85 & 55 & -110 & 8 & 5 & 5 & 11 & 0 \\
\hline 18 & 940808 & $19: 48: 42.75$ & 38.044 & 14.641 & 10.29 & 3.4 & 91 & 0.29 & 27 & 0 & 170 & 25 & -60 & 13 & 15 & 5 & 15 & 1 \\
\hline 19 & 941107 & $10: 26: 04.69$ & 38.821 & 15.210 & 10.05 & 3.7 & 124 & 0.39 & 35 & 6 & 95 & 60 & -100 & 20 & 8 & 10 & 12 & 1 \\
\hline 20 & 941127 & $07: 26: 28.14$ & 38.363 & 14.875 & 11.38 & 3.7 & 58 & 0.33 & 31 & 0 & 305 & 85 & -150 & 3 & 8 & 10 & 16 & 0 \\
\hline 21 & 950308 & $08: 55: 08.83$ & 37.796 & 15.559 & 4.81 & 3.7 & 148 & 0.37 & 24 & 13 & 160 & 25 & -60 & 3 & 3 & 10 & 15 & 2 \\
\hline 22 & 950827 & $19: 42: 14.20$ & 38.279 & 15.165 & 8.91 & 4.0 & 62 & 0.42 & 25 & 9 & 225 & 85 & 0 & 3 & 18 & 10 & 13 & 1 \\
\hline 23 & 960714 & $00: 32: 44.06$ & 37.812 & 14.880 & 22.82 & 3.6 & 87 & 0.17 & 16 & 11 & 160 & 50 & 90 & 20 & 18 & 10 & 12 & 0 \\
\hline 24 & 000208 & $11: 19: 20.14$ & 37.837 & 15.805 & 31.54 & 2.5 & 173 & 0.27 & 20 & 16 & 40 & 30 & -30 & 0 & 0 & 10 & 12 & 1 \\
\hline 25 & 000208 & $22: 19: 39.76$ & 37.876 & 15.565 & 25.98 & 2.6 & 137 & 0.35 & 27 & 19 & 205 & 45 & -30 & 25 & 8 & 25 & 24 & 4 \\
\hline 26 & 000308 & $09: 38: 43.52$ & 38.229 & 15.745 & 13.31 & 3.0 & 58 & 0.27 & 18 & 12 & 50 & 30 & -150 & 8 & 10 & 5 & 13 & 1 \\
\hline 27 & 000317 & $06: 35: 04.85$ & 37.970 & 15.931 & 10.92 & 3.3 & 157 & 0.14 & 21 & 9 & 85 & 65 & -90 & 5 & 5 & 15 & 10 & 1 \\
\hline 28 & 000404 & $13: 38: 17.32$ & 37.756 & 14.898 & 18.59 & 2.9 & 69 & 0.17 & 22 & 15 & 100 & 40 & -180 & 10 & 5 & 15 & 10 & 0 \\
\hline 29 & 000529 & $14: 25: 31.86$ & 38.153 & 15.118 & 9.03 & 3.0 & 84 & 0.17 & 21 & 15 & 5 & 55 & -130 & 8 & 8 & 10 & 10 & 0 \\
\hline 30 & 000615 & $21: 25: 07.39$ & 38.905 & 15.911 & 33.90 & 3.0 & 100 & 0.31 & 18 & 11 & 135 & 60 & 80 & 10 & 5 & 0 & 10 & 1 \\
\hline 31 & 001120 & $23: 41: 55.00$ & 37.842 & 14.941 & 23.71 & 3.3 & 62 & 0.17 & 19 & 11 & 75 & 50 & 80 & 8 & 10 & 10 & 11 & 0 \\
\hline 32 & 010307 & $17: 20: 26.15$ & 37.913 & 14.868 & 28.94 & 2.9 & 98 & 0.22 & 22 & 13 & 95 & 70 & -150 & 10 & 10 & 30 & 11 & 0 \\
\hline
\end{tabular}

Order number, date, origin time, epicenter latitude and longitude, focal depth, duration magnitude, maximum azimuthal gap of the network around the epicenter, standard deviation of the arrival time residuals, number of $\mathrm{P}$ and $\mathrm{S}$ effectively used for the hypocentral location, strike, dip and rake of one of the nodal planes (and related uncertainties), number of $\mathrm{P}$ onset polarities used for focal mechanism computation, and number of discrepancies between theoretical and observed polarities. 
nally, Fig. $7 \mathrm{~h}$ displays the orientations of the stress principal axes estimated for the CALMES subset of fault plane solutions, the only subset in Fig. 6 for which the inversion led to an acceptably uniform and constrained stress.

Fig. 8 shows the locations and mechanisms of the events of magnitude over 5.0 occurring in the crust of the study area between January 1978 and March 2001. These were: (i) the March 11, 1978, southern Calabria earthquake of magnitude 5.6, almost pure normal faulting mechanism [60], (ii) the April 15, 1978, Gulf of Patti earthquake of magnitude 5.5, dextral strike-slip with minor reverse component [28,61], and (iii) the May 28, 1980, western Aeolian Islands earthquake of magnitude 5.7, reverse mechanism with minor dextral strike-slip component [28,61]. Since the quality of the fault plane solutions we estimated for these events using polarity data from local stations was not suitable for inclusion in Fig. 6, we report in the present study (Fig. 8 and Table 2) the focal parameters estimated by other investigators using

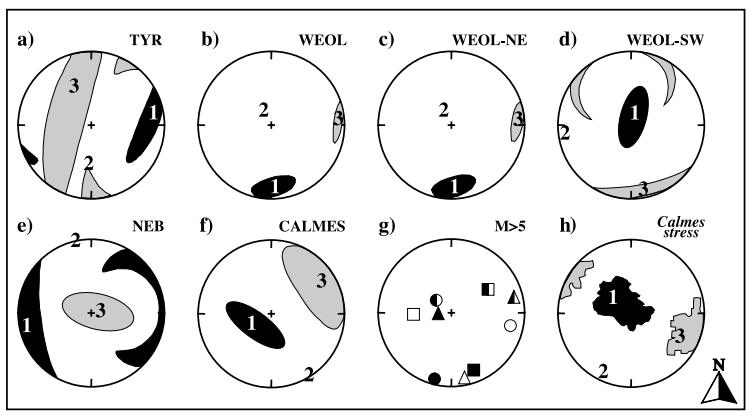

Fig. 7. a-f show the orientations of the principal strain axes obtained from the fault plane solutions of Fig. 6 for the subsets TYR (a), WEOL (b), WEOL-NE (c), WEOL-SW (d), NEB (e), CALMES (f). Numbers 1, 2 and 3 indicate the orientations of the maximum, intermediate and minimum compressive strain, respectively, the black and gray zones indicate the $95 \%$ confidence areas of $\varepsilon_{1}$ and $\varepsilon_{3}$. Circles, squares and triangles in $\mathrm{g}$ indicate the strain orientations relative to the $M>5$ earthquakes that occurred in April 1978 (Gulf of Patti), May 1980 (western Aeolian Islands) and March 1978 (southern Calabria), respectively. Full, half filled and empty symbols represent $\varepsilon_{1}, \varepsilon_{2}$ and $\varepsilon_{3}$, respectively. h displays the orientations of the stress principal axes estimated for the CALMES subset of fault plane solutions, the only subset in Fig. 6 for which the inversion led to an acceptably uniform and constrained stress. Black and gray indicate the $95 \%$ confidence areas of $\sigma_{1}$ and $\sigma_{3}$, respectively.

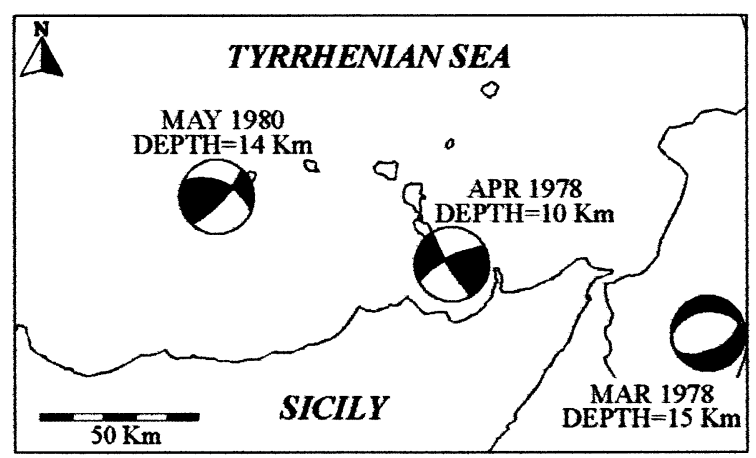

Fig. 8. Locations and fault plane solutions (lower hemisphere projection) of the $M>5$ earthquakes that occurred in the crust of the study area between January 1978 and March 2001. Focal parameter values of these events are reported in Table 2 together with the bibliographic sources.

other techniques and datasets. As specified above, the orientations of the principal strain axes relative to these events are shown in Fig. 7 g. Joint analysis of Figs. 6-8 reveals that in the sectors where strong earthquakes $(M>5.0)$ occurred in the study period (CALMES and WEOL) the deformation style associated with low-magnitude earthquakes (2.5-4, approximately) was practically the same as related to strong events. Moreover, it is worth noting that events having magnitude over 5 occurred in a time span of 27 months that is rather small compared with the duration of the study period (23 years). The epicenters of these events are aligned (Fig. 8) and the spacetime evolution of this temporal cluster marks a sort of propagation of the activity from ESE to WNW. This is a stimulus for future investigations of tectonic stress propagation in this area.

\section{Discussion and conclusion}

The seismic strain and seismogenic stress orientations estimated for the southern Tyrrhenian region are schematically reported in Fig. 9. Black arrows with codes M80, A78 and M78 indicate, respectively, the strain orientations associated with the magnitude over five earthquakes of May 1980, April 1978 and March 1978, that we inferred from the fault plane solutions of these events reported in the literature (complete infor- 
mation is given in Fig. $7 \mathrm{~g}$ ). Black arrows without code show the strain orientations estimated in the present work (see also Fig. 7b and f). Gray arrows show the seismogenic stress found beneath the western part of the etnean area by Cocina et al. [62]. White arrows indicate the stress orientation in the Messina Strait southern Calabria area coming from the stress inversion performed in the present study (see also Fig. 7h). In addition, the seismicity map of Fig. 5 has been included in Fig. 9 after elimination of the events deeper than 32.5 $\mathrm{km}$ and conversion of the epicenter plot into a darkening map, with darkening proportional to the number of epicenters per surface unit.

Compressional seismic strain with maximum shortening oriented about north-south can be observed west of Milazzo Cape in Fig. 9, in the proximity of the main fault systems Sisifo and Vulcano. Several tens of $\mathrm{km}$ to the south, beneath western Etna, Cocina et al. [62] found northsouth compression by stress inversion of local earthquake fault plane solutions (gray arrows in Fig. 9). It can also be considered that Cocina et al. [62] evidenced a high degree of stress heterogeneity beneath eastern Etna, an area interpreted as being transitional between the compressive domain of western-central Sicily and the tensional domain of the western Ionian and the Calabrian Arc. Fig. 9 also reports minor extensional processes to the south of the Sisifo compressional structure, in the WEOL-SW sector of Fig. 6 characterized by low-magnitude normal faulting seismicity. To the east, a major extensional domain is identified in the Messina Strait southern Calabria area (Fig. 9). In particular, the minimum compressive strain $\varepsilon_{3}$ associated with the events of magnitude in the range $2.4-3.7$ is oriented ca. $45^{\circ} \mathrm{N}$ and constrained between $10^{\circ} \mathrm{N}$ and $100^{\circ} \mathrm{N}$

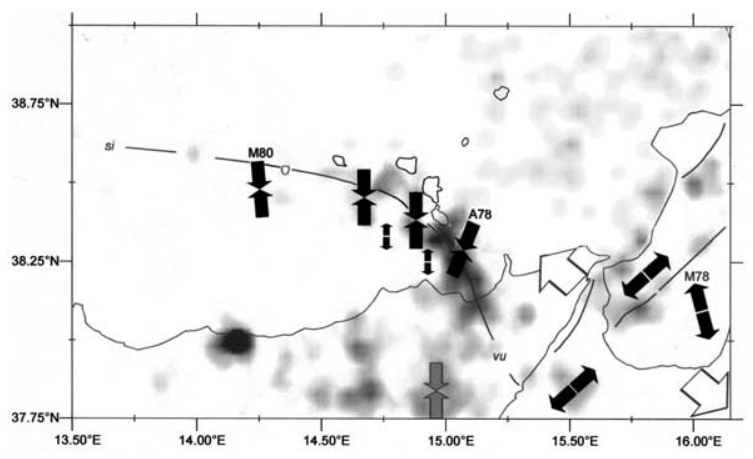

Fig. 9. Sketch representation of the seismic strain styles in the study region. Black arrows with codes M80, A78 and M78 indicate the strain associated with the $M>5$ earthquakes that occurred in May 1980, April 1978 and March 1978 (see Fig. 7g). Black arrows without code show the strain orientations estimated in the present work (Fig. 7b and f). Gray arrows show the seismogenic stress found by Cocina et al. [62] in the western Etna area. White arrows indicate the stress orientation in the Messina Strait southern Calabria area coming from the stress inversion performed in the present study (Fig. 7h). The trends of the main fault systems are schematically represented in the zones where we propose stress and strain estimates ( $s i$ and $v u$ stand for Sisifo and Vulcano, respectively). Also, the seismicity map of Fig. 5 has been included in this figure after elimination of the events deeper than $32.5 \mathrm{~km}$ and conversion of the epicenter plot into a darkening map, with darkening proportional to the number of epicenters per surface unit.

(see also Figs. 7f and 6, CALMES). The minimum compressive stress $\sigma_{3}$ estimated by stress inversion of the same events is oriented ca. $110^{\circ} \mathrm{N}$ and constrained between $90^{\circ} \mathrm{N}$ and $135^{\circ} \mathrm{N}$ (Fig. 7h, and white arrows in Fig. 9). This stress orientation is coherent with the main stress field inferred from geological data in the same area ([17]; among others). Because quite conservative confidence limits of stress and strain orientations are used in the present study and reported in Fig.

Table 2

Main parameters of the earthquakes reported in Fig. 8

\begin{tabular}{llllllrrrr}
\hline Date & O.T. & $\begin{array}{l}\text { Lat } \\
\left({ }^{\circ} \mathrm{N}\right)\end{array}$ & $\begin{array}{l}\text { Long } \\
\left({ }^{\circ} \mathrm{E}\right)\end{array}$ & $\begin{array}{l}\text { Depth } \\
(\mathrm{km})\end{array}$ & Mag & Strike & Dip & Rake & BIB \\
\hline 780311 & 19.20 & 38.10 & 16.03 & 15 & 5.6 & 270 & 41 & -72 & 1 \\
780415 & 23.33 & 38.29 & 15.07 & 10 & 5.5 & 239 & 71 & 7 & 2,3 \\
800528 & 19.51 & 38.48 & 14.25 & 14 & 5.7 & 41 & 71 & 48 & 2,3 \\
\hline
\end{tabular}

Date, origin time, epicenter latitude and longitude, focal depth, magnitude, strike, dip and rake of one of the nodal planes, and bibliographic source (1: [60]; 2: [28]; 3: [61]). 
7, we deduce from Fig. $7 \mathrm{~h}$ and $\mathrm{f}$ that $\varepsilon_{3}$ orientation was quite different from $\sigma_{3}$ orientation during 1978-2001 in the Messina Strait southern Calabria area. It can also be observed in Fig. 9 that $\sigma_{3}$ is nearly orthogonal to the trend of the main fault systems in the same area. We may reasonably infer from these results that the seismic events investigated in the Messina Strait southern Calabria area were not, in general, produced by the main faults, but by minor faults activated by the main stress field working in this area.

It was said in the previous section that the CALMES subset of fault plane solutions in Fig. 6 (eastern sector of the study area) was the only dataset for which the inversion led to an acceptably uniform and constrained stress. Plot $\sigma A$ in Fig. 10 displays the result obtained by stress inversion of the subset of Fig. 6 including all the events located in the western sector of the study area (WEOL-NE, WEOL-SW, NEB, and the event nos. 17 and 18; hereafter dataset $A$ ). The extent of the confidence areas of $\sigma_{1}$ and $\sigma_{3}$, and the relatively large value of the average misfit $M$ between stress tensor and fault plane solutions, reveal a certain degree of stress heterogeneity in the dataset (see [7] for details on misfit analysis). Plot $\sigma B$ in the same figure shows the results of an inversion experiment performed after integration of fault plane solutions of dataset $A$ with 11 fault plane solutions selected from those proposed by Cocina et al. [62] for the western Etna area (see caption of Fig. 10 for details). We based this selection on our knowledge of Cocina et al.'s fault plane solutions and on the need to obtain an integrated dataset $(B)$ where quality was as uniform as possible. Although diagram $\sigma B$ in Fig. 10 shows a greater constraint of stress orientations and an increased definition of a compressional stress regime compared to $\sigma A$, the result confirms the presence of a significant degree of stress heterogeneity in the crustal volume under investigation. This provides additional proof that unconstrained stress from inversion of dataset $A$ was not an effect of few incompatible fault plane solutions within a small dataset but closely derived from stress heterogeneity in the western sector of the study area. Further inversion attempts not

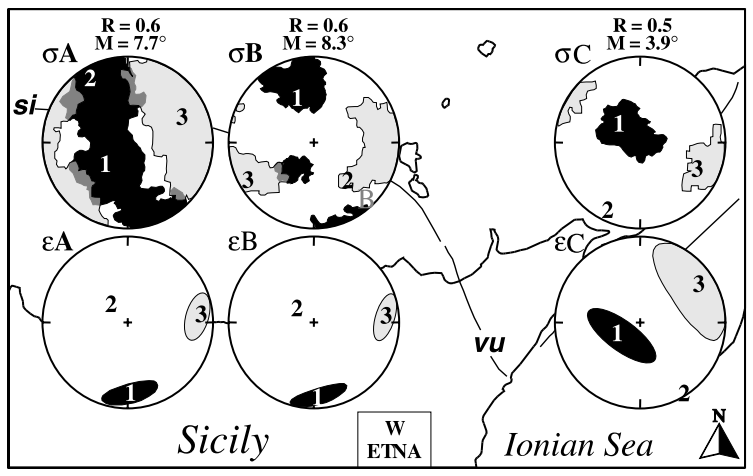

Fig. 10. Plots $\sigma A, \sigma B$ and $\sigma C$ display the stress orientations estimated for seismic datasets $A$ (event nos. 17, 18, WEOL and NEB in Fig. 6), $B$ (dataset $A$ plus Cocina et al.'s fault plane solutions listed below in this caption), and $C$ (CALMES in Fig. 6). Numbers 1, 2 and 3 in the $\sigma$ plots indicate the orientations of maximum, intermediate and minimum compressive stress, respectively. Black and light gray indicate the $95 \%$ confidence areas of $\sigma_{1}$ and $\sigma_{3}$, respectively, unless zones where these overlap (dark gray). Values of the inversion parameter $R=\left(\sigma_{1}-\sigma_{2}\right) /\left(\sigma_{1}-\sigma_{3}\right)$ are reported above the respective plots together with the average misfit $M$ between stress model and fault plane solutions. Plots $\varepsilon A, \varepsilon B$ and $\varepsilon C$ display the strain orientations estimated for datasets $A, B$ and $C$, with numbers 1,2 and 3 indicating maximum, intermediate and minimum compressive strain, and black and light gray showing the $95 \%$ confidence areas of $\varepsilon_{1}$ and $\varepsilon_{3}$, respectively. 'W ETNA' indicates the location area of Cocina et al.'s earthquakes selected for inclusion in dataset $B$ : these were earthquake nos. $3,4,5,9,10,11,12,14,16,32$ and 50 of Cocina et al.'s table 2, and were included in $B$ with weight $1,1,1,2,2,2,2,1,2,2$ and 2 , respectively.

reported herein for conciseness evidenced that a better definition of stress heterogeneities in this sector requires more fault plane solutions of high quality than presently available and their appropriate space distribution. On the other hand, strain orientation estimates relative to datasets $A$ and $B$ ( $\varepsilon A$ and $\varepsilon B$ in Fig. 10) evidence that compressional features are dominant in this sector. This is because 'compressional' seismic events are stronger than 'extensional' ones in $A$ and $B$, and strain orientation estimates (diversely from stress orientation ones) require seismic moment involvement in the computational algorithm [49,50]. Finally, Fig. 10 reproposes in the diagrams $\sigma C$ and $\varepsilon C$ the stress and strain orientations found in the eastern sector of the study area (Fig. 7h,f) and furnishes additional informa- 
tion concerning the stress inversion parameter $R$ and the average misfit $M$. The low value of $M$ $\left(3.9^{\circ}\right)$ is a further evidence of the already discussed uniformity of seismogenic stress in this specific sector.

As previously mentioned, several investigators have explained many geological and geophysical data of the southern Tyrrhenian region in the framework of a geodynamic model assuming gravity-induced southeastward rollback of an Ionian lithosphere slab subducting beneath the Tyrrhenian lithosphere. This hypothesis does not rule out the possibility of a concomitant north-south slow convergence between the African and European plates in the same region. Negredo et al. [27] proposed a 3D finite element modelling of the regional geodynamics where the slab rollback and plate convergence act together, and showed that this model satisfactorily explains the neotectonic data of Fig. 1a and the GPS measurements available in the Italian peninsular area. The model predicts a compressive stress oriented about NNE-SSW in the Aeolian Islands area and this is compatible with the results of the present investigation, in particular with the seismic strain orientations estimated in the same area and shown in Fig. 9 (e.g. stress, strain and seismogenic fault orientations are consistent). This implies that our seismic findings are compatible with the geodetic data referred to in Negredo et al.'s study and also that the model proposed by these authors may represent a possible unifying view of the seismic processes occurring at different depths (surface to $500 \mathrm{~km}$ ) in the study region. A comparison between Negredo et al.'s model and our results cannot be performed in the Messina Strait southern Calabria area for the simple reason that the southern boundary of this model was located north of Messina Strait. It can, however, be noted that the stress orientation we found in this area (Figs. 7h and 9) is compatible with the southeastward orientation of the Ionian slab rollback suggested by previous investigators (see Fig. 1 and Section 2). With regard to Mantovani et al.'s geodynamic model [31-33] based on the assumption that plate convergence is the only driving mechanism of regional tectonics, we have to point out that this model represents all the physical param- eters in the horizontal plane (2D model) and the attempted comparison of the model with our stress and strain tensors characterized by vertical $\sigma_{1}$ and $\varepsilon_{1}$ (Fig. 7h and f) could not be conclusive as regard to matching.

In conclusion, the study area may - in a first approximation - be divided in two main subareas, a western one affected by some degree of stress heterogeneity with an apparent prevalence of a compressional regime presumably induced by plate convergence, and an eastern one characterized by a NW-SE oriented extension eventually related to the locally prevailing action by the Ionian subduction slab rollback. During the 24-year period covered by our investigation the western sub-area was affected by moderate seismicity (maximum magnitude 5.7) mostly associated with compressional processes along NW-SE striking major fault systems. Maximum magnitude was close to the highest values (5.9) reported in the historical earthquake catalogue for the same sector. This evidence, and the coherence of seismic strain observed during 1978-2001 with the main structural and tectonic features of this subarea, allow us to believe that the seismic activity in the study period reproduced fairly well the general features of seismicity in this specific sector, even though other important seismogenic faults in it may have been inactive in so a relatively short period of time. In the eastern sub-area (Messina Strait southern Calabria) seismicity reached a maximum magnitude of 5.6 during 1978-2001, therefore a value remarkably lower than the top values of 7-7.5 reported in the historical earthquake catalogue. In addition, while seismogenic stress found to act in this sub-area over the study period is coherent with the main stress field inferred from geological data (and orthogonal to the main fault systems), seismic strain shows an orientation quite different from the stress one and suggests that seismicity between 1978 and 2001 was not, in general, produced by the main faults but by minor faults, however activated by the main stress field working in this area. Based on this evidence and on the relatively low magnitudes recorded in the study period, we are led to believe that seismic events between 1978 and 2001 in the Messina Strait southern Calabria 
area represented only minor effects of the intense dynamics of the local tectonic units.

\section{Acknowledgements}

The present work was financed by Istituto $\mathrm{Na}$ zionale di Geofisica e Vulcanologia in the framework of a collaboration agreement between INGV and Messina University.[SK]

\section{References}

[1] P. Ambrosetti, C. Bosi, F. Carraro, N. Ciaranfi, M. Panizza, G. Papani, L. Vezzani, A. Zanferrari, Neotectonic map of Italy, Progetto Finalizzato Geodinamica, Quaderni della Ricerca Scientifica vol. 4, 1987.

[2] GNDT (Gruppo Nazionale per la Difesa dai Terremoti), NT4.1 Catalogo parametrico di terremoti di area italiana al di sopra della soglia del danno, http://emidius.mi. ingv.it/NT, 1998.

[3] A. Hirn, R. Nicolich, J. Gallart, M. Laigle, L. Cernobori, ETNASEIS Scientific Group, Roots of Etna volcano in faults of great earthquakes, Earth Planet. Sci. Lett. 148 (1997) 171-191.

[4] Z. Gvirtzman, A. Nur, The formation of Mount Etna as the consequence of slab rollback, Nature 401 (1999) 782785.

[5] R. Nicolich, M. Laigle, A. Hirn, L. Cernobori, J. Gallart, Crustal structure of the Ionian margin of Sicily: Etna volcano in the frame of regional evolution, Tectonophysics 329 (2000) 121-139.

[6] C. Doglioni, F. Innocenti, G. Mariotti, Why Mt. Etna?, Terra Nova 13 (2001) 25-31.

[7] D. Caccamo, G. Neri, A. Saraò, M. Wyss, Estimates of stress directions by inversion of earthquake fault plane solutions in Sicily, Geophys. J. Int. 125 (1996) 857-868.

[8] G. Neri, D. Caccamo, O. Cocina, A. Montalto, Geodynamic implications of recent earthquake data in the Southern Tyrrhenian Sea, Tectonophysics 258 (1996) 233-249.

[9] G. De Luca, L. Filippi, D. Caccamo, G. Neri, R. Scarpa, Crustal structure and seismicity of Southern Tyrrhenian basin, Phys. Earth Planet. Inter. 103 (1997) 117-133.

[10] G. Barberi, D. Caccamo, G. De Luca, G. Neri, R. Scarpa, Seismic response to stress-strain fields in the lithosphere of Sicily, Ann. Geofis. 42 (5) (1999) 789-800.

[11] G. Neri, G. Barberi, B. Orecchio, M. Aloisi, Seismotomography of the crust in the transition zone between the southern Tyrrhenian and Sicilian tectonic domains, Geophys. Res. Lett. 29 (23) (2002) 2135.

[12] G. Selvaggi, C. Chiarabba, Seismicity and P-wave velocity image of the Southern Tyrrhenian subduction zone, Geophys. J. Int. 121 (1995) 818-826.
[13] C. Piromallo, A. Morelli, Imaging the Mediterranean upper mantle by P-wave travel time tomography, Ann. Geofis. 40 (1997) 963-979.

[14] G.B. Cimini, P-wave deep velocity structure of the Southern Tyrrhenian Subduction Zone from nonlinear traveltime tomography, Geophys. Res. Lett. 26 (1999) 37093712 .

[15] F.P. Lucente, C. Chiarabba, G.B. Cimini, Tomographic constraints on the geodynamic evolution of the Italian region, J. Geophys. Res. 104 (B9) (1999) 20307-20327.

[16] F. Lentini, S. Carbone, S. Catalano, M. Grasso, Principali lineamenti strutturali della Sicilia nord-orientale, Stud. Geol. Camerti Vol. Spec. 1995/2 (1995) 319-329.

[17] L. Tortorici, C. Monaco, C. Tansi, O. Cocina, Recent and active tectonics in the Calabrian Arc (Southern Italy), Tectonophysics 243 (1995) 37-55.

[18] C. Monaco, L. Tortorici, R. Nicolich, L. Cernobori, M. Costa, From collisional to rifted basins: an example from the southern Calabrian arc (Italy), Tectonophysics 266 (1996) 233-249.

[19] M. Bianca, C. Monaco, L. Tortorici, L. Cernobori, Quaternary normal faulting in the southeastern Sicily (Italy): a seismic source for the 1693 large earthquake, Geophys. J. Int. 139 (1999) 370-394.

[20] A. Malinverno, W.B.F. Ryan, Extension in the Tyrrhenian sea and shortening in the Apennines as result of Arc migration driven by sinking of the lithosphere, Tectonics 5 (1986) 227-245.

[21] A. Cinque, E. Patacca, P. Scandone, M. Tozzi, Quaternary kinematic evolution of the Southern Apennines. Relationship between surface geological features and deep lithospheric structures, Ann. Geofis. 36 (2) (1993) 249260.

[22] C. Faccenna, P. Davy, J.P. Brun, R. Funiciello, D. Giardini, M. Mattei, T. Nalpas, The dynamics of back-arc extension: an experimental approach to the opening of the Tyrrhenian Sea, Geophys. J. Int. 126 (1996) 781-795.

[23] C. Faccenna, T.W. Becker, F.P. Lucente, L. Jolivet, F. Rossetti, History of subduction and back-arc extension in the Central Mediterranean, Geophys. J. Int. 145 (2001) 809-820.

[24] C. Faccenna, F. Funiciello, D. Giardini, F.P. Lucente, Episodic back-arc extension during restricted mantle convection in the Central Mediterranean, Earth Planet. Sci. Lett. 187 (2001) 105-116.

[25] A. Argnani, The Southern Tyrrhenian subduction system: recent evolution and neotectonic implications, Ann. Geofis. 43 (3) (2000) 585-607.

[26] Z. Gvirtzman, A. Nur, Residual topography, lithospheric structure and sunken slabs in the central Mediterranean, Earth Planet. Sci. Lett. 187 (2001) 117-130.

[27] A.M. Negredo, R. Sabadini, G. Bianco, M. Fernandez, Three-dimensional modeling of crustal motions caused by subduction and continental convergence in the central Mediterranean, Geophys. J. Int. 136 (1999) 261-274.

[28] H. Anderson, J. Jackson, Active tectonics of the Adriatic region, Geophys. J. Astron. Soc. 91 (1987) 937-983. 
[29] W. Spakman, Tomographic images of the upper mantle below central Europe and the Mediterranean, Terra Nova 2 (1990) 512-553.

[30] G. Mele, High-frequency wave propagation from mantle earthquakes in the Tyrrhenian Sea: new constraints for the geometry of the south Tyrrhenian subduction zone, Geophys. Res. Lett. 25 (1998) 2877-2880.

[31] E. Mantovani, M. Viti, D. Albarello, C. Tamburelli, D. Babbucci, N. Cenni, Role of kinematically induced forces in Mediterranean tectonics: insights from numerical modeling, J. Geodyn. 30 (2000) 287-320.

[32] E. Mantovani, N. Cenni, D. Albarello, M. Viti, D. Babbucci, C. Tamburelli, F. D'Onza, Numerical simulation of the observed strain field in the central-eastern Mediterranean region, J. Geodyn. 31 (2001) 519-556.

[33] E. Mantovani, D. Albarello, D. Babbucci, C. Tamburelli, M. Viti, Trench-Arc-BackArc systems in the Mediterranean area: Examples of extrusion tectonics, in: G. Rosenbaum, G.S. Lister (Eds.), Reconstruction of the Evolution of the Alpine-Himalayan Orogen, Journal of the Virtual Explorer 8, 2002, pp. 125-141.

[34] M. Anzidei, P. Baldi, G. Casula, A. Galvani, E. Mantovani, A. Pesci, F. Riguzzi, E. Serpelloni, Insights into present-day crustal motion in the central Mediterranean area from GPS surveys, Geophys. J. Int. 146 (2001) 98110.

[35] I. Finetti, A. Del Ben, Geophysical study of the Tyrrhenian opening, Boll. Geofis. Teor. Appl. 110 (1986) 75-156.

[36] F. Ghisetti, L. Vezzani, Different styles of deformation in the Calabrian Arc (southern Italy): implications for a seismotectonic zoning, Tectonophysics 85 (1982) 149165.

[37] J.P. Rehault, E. Moussat, A. Fabbri, Structural evolution of the Tyrrhenian back-arc basin, Mar. Geol. 74 (1987) $123-150$.

[38] J. Van Dijk, M. Okkes, Neogene tectonostratigraphy and kinematics of Calabrian basins; implications for the geodynamics of the Central Mediterranean, Tectonophysics 196 (1991) 23-60.

[39] F. Ghisetti, Recent deformations and the seismogenic source in the Messina Strait (southern Italy), Tectonophysics 109 (1984) 191-208.

[40] F. Ghisetti, Fault parameters in the Messina Strait (southern Italy) and relations with the seismogenic source, Tectonophysics 210 (1992) 117-133.

[41] F. Mulargia, E. Boschi, The 1908 Messina earthquake and related seismicity, in: Earthquakes: Observation, Theory and Interpretation, Proc. Int. School Phys. 'E. Fermi', North-Holland Publ. Co., Amsterdam, 1983, pp. 493-518.

[42] E. Boschi, D. Pantosti, G. Valensise, Modello di sorgente per il terremoto di Messina del 1908 ed evoluzione recente dell'area dello Stretto, in: Atti del VIII Convegno Annuale del Gruppo Nazionale di Geofisica della Terra Solida, Roma, 7-9 Novembre, 1989.

[43] A. Bottari, P. Capuano, G. De Natale, P. Gasparini, G. Neri, F. Pingue, R. Scarpa, Source parameters of earth- quakes in the Strait of Messina, Italy, during in this century, Tectonophysics 166 (1989) 221-234.

[44] V. Cotecchia, A. Guerricchio, G. Melidoro, The geomorphogenetic crisis triggered by the 1783 earthquake in Calabria (Southern Italy), in: Proceedings of an International Symposium on Engineering geology problems in Seismic Areas vol. 6, Bari, 1986, pp. 245-304.

[45] E. Jacques, C. Monaco, P. Tapponier, L. Tortorici, T. Winter, Faulting and earthquake triggering during the 1783 Calabria seismic sequence, Geophys. J. Int. 147 (2001) 499-516.

[46] P. Galli, V. Bosi, Paleoseismology along the Cittanova fault: implications for seismotectonics and earthquake recurrence in Calabria (southern Italy). J. Geophys. Res. 107 (B3) (2002) ETG1 1-19.

[47] J.R. Evans, D. Eberhart-Phillips, C.H. Thurber, User's manual for simulps12 for imaging $V_{P}$ and $V_{P} / V_{S}$ : a derivative of the 'Thurber' tomographic inversion simul3 for local earthquakes and explosions, USGS Open-file Report 94-431, 1994.

[48] P.A. Reasenberg, D. Oppenheimer, FPFIT, FPPLOT AND FPPAGE: fortran computer programs for calculating and displaying earthquake fault-plane solutions, USGS Open-file Report 85-739, 1985.

[49] M. Wyss, B. Liang, W.R. Tanigawa, X. Wu, Comparison of orientations of stress and strain tensors based on fault plane solutions in Koiki, Hawaii, J. Geophys. Res. 97 (1992) 4769-4790.

[50] B. Kostrov, Seismic moment and energy of earthquakes, and seismic flow of rocks, Izv. Acad. Sci. USSR Phys. Solid Earth 1 (1974) 23-40.

[51] A.A. Kiratzi, Active seismic deformation in the Italian peninsula and Sicily, Ann. Geofis. 37 (1) (1994) 27-45.

[52] W.H. Bakun, Seismic moments, local magnitudes, and coda-duration magnitudes for earthquakes in Central California, Bull. Seism. Soc. Am. 74 (1984) 439-458.

[53] F.R. Zúñiga, M. Wyss, F. Scherbaum, A moment-magnitude relation for Hawaii, Bull. Seism. Soc. Am. 78 (1988) 370-373.

[54] J.W. Gephart, W.D. Forsyth, An improved method for determining the regional stress tensor using earthquake focal mechanism data: Applications to the San Fernando earthquake sequence, J. Geophys. Res. 89 (1984) 93059320.

[55] F. Ghisetti, Relazioni tra strutture e fasi trascorrenti e distensive lungo i sistemi Messina-Fiumefreddo, TindariLetojanni e Alia-Malvagna (Sicilia nord-orientale): uno studio microtettonico, Geol. Rom. 18 (1979) 23-58.

[56] R.M. Azzara, A. Amato, A. Basili, C. Chiarabba, G.B. Cimini, M. Cocco, R. Console, M. Di Bona, A. Frepoli, S. Mazza, G. Selvaggi, Studio di dettaglio di una struttura sismogenetica attiva nella zona di Pollina (Sicilia settentrionale), in: Atti del XII Convegno Annuale del Gruppo Nazionale di Geofisica della Terra Solida, Roma, 24-26 Novembre, 1993, pp. 205-206.

[57] R. Azzaro, M.S. Barbano, The Pollina (Northern SicilyItaly) earthquakes of 26 June 1993: an application of the 
new European Macroseismic Scale 1992, Nat. Hazards 12 (1995) 289-301.

[58] M. Boccaletti, R. Nicolich, L. Tortorici, New data and hypothesis on the development of the Tyrrhenian basin, Palaeogeogr. Palaeoclimatol. Palaeoecol. 77 (1990) 15-40.

[59] G. Giunta, F. Nigro, Tectono-sedimentary constraints to the Oligocene-to-Miocene evolution of the Peloritani thrust belt (NE Sicily), Tectonophysics 315 (1999) 287299.

[60] A.M. Dziewonski, G. Ekström, J.E. Franzen, J.H. Wood- house, Global seismicity of 1978: centroid-moment tensor solutions for 512 earthquakes, Phys. Earth Planet. Inter. 46 (1987) 316-342.

[61] C. Gasparini, G. Iannaccone, R. Scarpa, Fault-plane solutions and seismicity of the italian peninsula, Tectonophysics 117 (1985) 59-78.

[62] O. Cocina, G. Neri, E. Privitera, S. Spampinato, Stress tensor computations in the Mount Etna area (Southern Italy) and tectonic implications, J. Geodyn. 23 (1997) 109-127. 